\title{
Analytic Hierarchy Process (AHP) for a Landfill Site Selection in Chachapoyas and Huancas (NW Peru): Modeling in a GIS-RS Environment
}

\author{
Jhonsy O. Silva López $\mathbb{D}^{D}$, Rolando Salas López $\mathbb{i}$, Nilton B. Rojas Briceño $\mathbb{B}$, \\ Darwin Gómez Fernández $\mathbb{D}$, Renzo E. Terrones Murga $(\mathbb{D}$, Daniel Iliquín Trigoso (D), \\ Elgar Barboza Castillo $\mathbb{D}^{D}$, Manuel Oliva Cruz $\mathbb{B}^{\text {, }}$, and Miguel Ángel Barrena Gurbillón \\ Instituto de Investigación para el Desarrollo Sustentable de Ceja de Selva (INDES-CES), \\ Universidad Nacional Toribio Rodríguez de Mendoza de Amazonas (UNTRM), Chachapoyas 01001, Peru
}

Correspondence should be addressed to Jhonsy O. Silva López; jhonsy.silva@untrm.edu.pe and Nilton B. Rojas Briceño; nrojas@ indes-ces.edu.pe

Received 7 October 2021; Revised 11 December 2021; Accepted 21 December 2021; Published 17 January 2022

Academic Editor: Xueping Fan

Copyright ( 2022 Jhonsy O. Silva López et al. This is an open access article distributed under the Creative Commons Attribution License, which permits unrestricted use, distribution, and reproduction in any medium, provided the original work is properly cited.

\begin{abstract}
The evaluation of suitable landfill sites is a complex process and requires various legislative, technical, social, and environmental criteria. Therefore, this study provides a management tool for identifying suitable sites for landfills through the integrated use of the analytic hierarchy process (AHP), geographic information systems (GISs), and remote sensing (RS). Accordingly, fourteen subcriteria were identified and grouped into physical (7), environmental (3), and socioeconomic (4) criteria and were weighed using pairwise comparison matrices (PCMs). The weighted linear combination (WLC) approach of maps allowed us to generate models and submodels of land suitability. From the territory of the districts of Chachapoyas and Huancas, $0.9 \%\left(1.71 \mathrm{~km}^{2}\right), 71.1 \%$ $\left(141.89 \mathrm{~km}^{2}\right), 21.0 \%\left(41.86 \mathrm{~km}^{2}\right), 0.0 \%$, and $7.7 \%\left(14.21 \mathrm{~km}^{2}\right)$ have highly suitable, moderately suitable, marginally suitable, unsuitable, and restricted conditions, respectively, for a landfill site. Twelve highly suitable sites were identified, of which three were selected based on their shape and the minimum area required for the operation of the landfill until 2040. In fact, this study proposes a management tool for decision-makers (DMs) that improve the process of selecting landfill sites, supported by engineering and its applications for territorial sustainability.
\end{abstract}

\section{Introduction}

The generation of large volumes of solid waste is linked to the exponential demand for food, urbanization, and global overpopulation [1]. It is expected that in the following 30 years, the generation of solid waste will increase by $70 \%$ [2]. Therefore, this is a global environmental problem and adequately addressing, managing, and disposing of this waste pose enormous challenges [3-5]. In this context, solid waste management plays a vital role in urban planning $[6,7]$; in developing countries, the most economical technique for the final disposal of solid waste is landfills [8, 9]. Namely, 54.4\% of the population in Latin America and the Caribbean dispose of their waste in landfill sites [10]. In Peru, in 2018, 7 342713 tons of municipal solid waste (MSW) were generated, of which only $1.05 \%$ were revalued, and only $49.16 \%$ were disposed of in authorized final disposal infrastructure (FDI) [11]. In particular, in Peru (for more than 32 million inhabitants), there are only 58 FDIs (6 secure landfills, 49 landfills, and 3 mixed landfills) and are located in only 19/25 regions [12].

Currently, the best and common technique for the final disposal of solid waste is the establishment of landfills [13-15]. However, determining the location of a landfill is a highly complex and tedious task, mainly because there are many factors and strict regulations involved in the selection 
process $[3,16]$. The inadequate selection of the disposal site and poor management of the landfill infrastructure can become a problem with strong environmental, social, and economic impacts that threaten public health $[17,18]$. The inappropriate placement of a landfill site is the main factor influencing the biophysicochemical characteristics of the environment and the ecology of the surrounding area [19-21].

The proper selection of a site for a landfill is a process that requires the evaluation of various environmental, financial, social, and technical criteria [17, 18, 22]. Methodologies have arisen that incorporate geographic information systems (GISs), remote sensing (RS), and multicriteria decision analysis (MCDA) through the analytic hierarchy process (AHP) [13, 23-28]. GISs are efficient in collecting, manipulating, interacting, and analyzing spatial data (many of which come from RS) that apply to the criteria for the selection of the ideal site [29-32], while the AHP is one of the most commonly used MCDA techniques for determining the relative importance of the criteria [26, 33-35]. These tools have been integrated into several studies [9, 36, 37] because they are effective in simplifying the selection of the optimal landfill sites [7, 28, 38-41]. For Amazonas, one of the 10 poorest regions of Peru [42], this methodology represents an important management tool for the proper beginning of MSW management.

This study identified suitable sites for landfills in the districts of Chachapoyas and Huancas (Amazonas, NW Peru) with the MCDA through the AHP in a GIS-RS environment, thus facilitating the planning of the territory in accordance with the physical, environmental, and socioeconomic criteria in order to avoid future negative impacts. Moreover, it also considered a 20-year projection of a landfill site based on the population growth rate, MSW volume, minimum area, and landform. In effect, this study not only provides a local management tool for decision-makers (DMs), but it may also be used in other regions since the methodology can be easily replicated with the necessary complements adjusted to the local reality.

\section{Materials and Methods}

2.1. Study Area. The districts of Chachapoyas and Huancas are located in the province of Chachapoyas, which is in the Amazonas region in the NW of Peru (Figure 1; $6^{\circ} 27^{\prime} 45^{\prime \prime}-6^{\circ} 48^{\prime} 07^{\prime \prime} \mathrm{S}$ and $\left.77^{\circ} 43^{\prime} 05^{\prime \prime}-77^{\circ} 49^{\prime} 51^{\prime \prime} \mathrm{W}\right)$. The total surface area represents approximately $199.67 \mathrm{~km}^{2}$, with an average annual temperature of $15.6^{\circ} \mathrm{C}$ and annual accumulated rainfall of $811 \mathrm{~mm}$. Chachapoyas is the second most populated city and the administrative center in the region. It has high economic, commercial, and tourist activities. The city is expanding at a rapid pace, with new areas of human settlement. This is due to the creation of the National University Toribio Rodríguez de Mendoza de Amazonas (Universidad Nacional Toribio Rodríguez de Mendoza de Amazonas-UNTRM) in 2000, which has influenced the migration of the rural population. As a consequence, the population of Chachapoyas increased from 32,026 to 42,350 inhabitants in the period of 1997-2017 [43]. Chachapoyas generates $0.434 \mathrm{~kg} /$ inhab-day of MSW (the national average of 2014-2018 was $0.520 \mathrm{~kg} /$ inhab-day [44]), with a total of 5169.86 MT/year [45]. This MSW is disposed of in "El Atajo" or "Rondón" open waste disposal sites (OWDS) (Figure 1; $1.12 \mathrm{ha} ; 6^{\circ} 13^{\prime} 10^{\prime \prime} \mathrm{S}$ and $77^{\circ} 50^{\prime} 21^{\prime \prime} \mathrm{W}$ ), located $3.81 \mathrm{~km}$ (in a straight line) from the city center. This OWDS has been open for more than 40 years and is considered one of the 1585 areas degraded by MSW in Peru, and this area is still getting 31.81 MT/day of MSW [46]. This OWDS poses a great challenge for the population and DMs due to the environmental impact on the air (this site has constantly conducted burning operations for 10 years), landscape, soil, and water (this site has direct contact with El Atajo Creek) [47]. Therefore, the selection of possible sites for a controlled and authorized landfill is essential and of great importance for the main towns and cities, especially in developing countries such as Peru. This study seeks to provide the authorities with an alternative for selecting potential sites to establish a sanitary landfill in order to curb the current negative impacts by the current OWDS impacts on natural resources. In the selection process, we integrate the territory of the Huancas district to strategically form the Chachapoyas-Huancas community because, in the national strategy, the FDI-MSWs are only built for commonwealths rather than municipalities or districts.

2.2. Methodological Design. Figure 2 shows the procedure used to model the suitability of the territory to identify a landfill suitable site. In summary, (i) criteria and subcriteria were identified and evaluated for a landfill location, (ii) a GIS database of the criteria and subcriteria was constructed, while the importance of each criterion was weighted by MCDA-AHP, (iii) submodels and the final suitability model were generated from weighted superposition, and finally, and (iv) the very adequate sites were evaluated according to future requirements of the area and shape.

\subsection{Identification and Selection of Criteria and Subcriteria.} The selection of the appropriate criteria is the main task for any type of analysis of land suitability, and it differs according to the objectives and the geographical scope [31]. Through a literature review, hierarchy levels were established based on three criteria and 14 subcriteria: seven physical, three environmental, and four socioeconomic (Figure 3). The shape and type of terrain are important for preventing contamination from a landfill, as well as for reducing the costs of drilling and leveling irregular terrain [48]. Therefore, the physical variables considered were as follows: the elevation, slope, soil texture, proximity to geological faults, and geology type as well as the meteorological variables such as rainfall and average annual temperature $[36,49]$, which are very important for landfills due to the influence of these parameters on the generation of leachates and the decomposition rate of MSW [48]. Within environmental subcriteria $[17,50]$, the proximity to surface waters, type of geology, proximity to protected natural areas (PNAs), and land use/land cover (LULC) were considered. Finally, for socioeconomic subcriteria, which is based on 


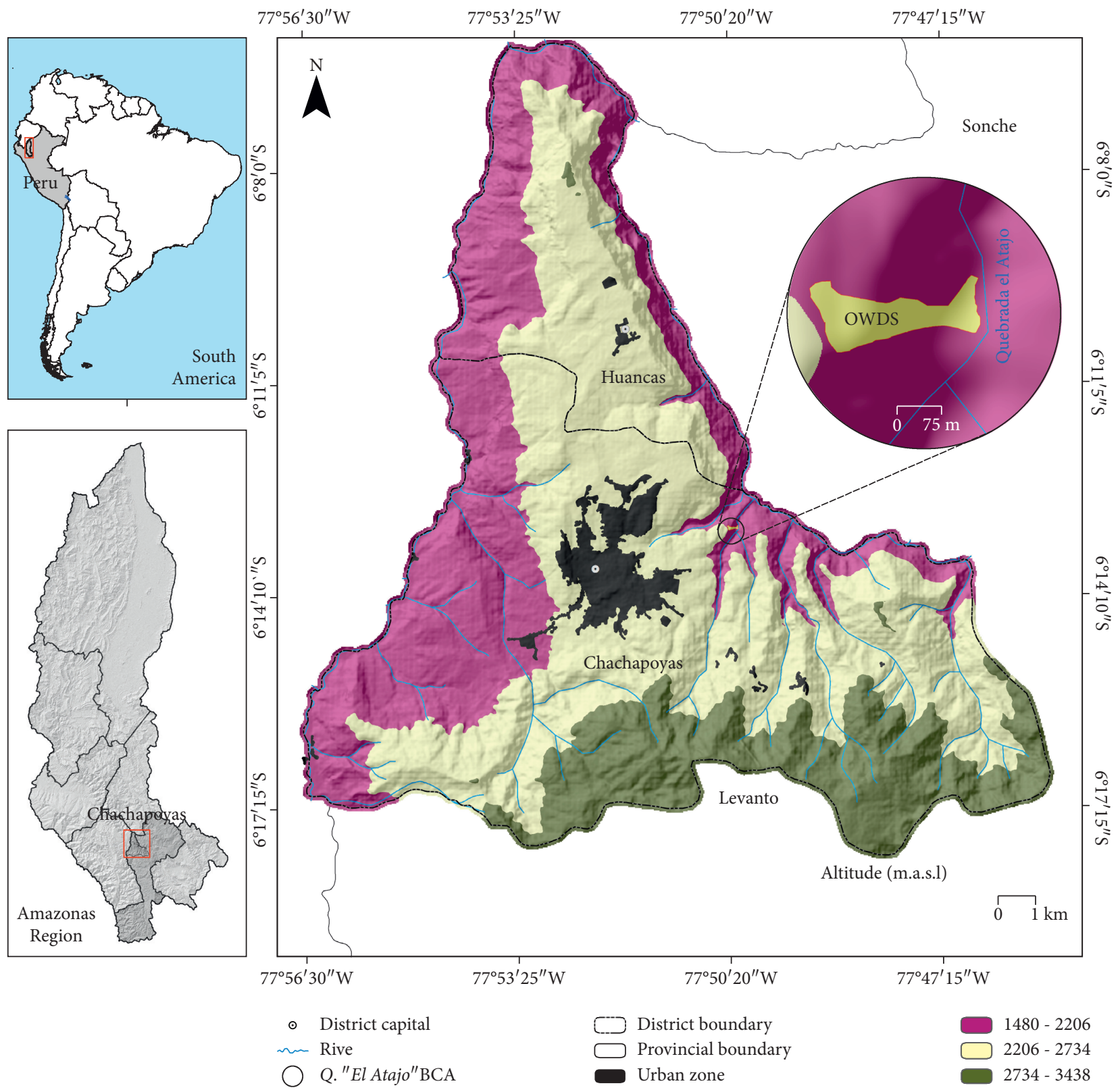

Figure 1: Location of the districts of Chachapoyas and Huancas, Amazonas, NW Peru.

criteria established by the Ministry of Environment (MINAM) [51], it was considered proximity to access to roads, urban areas, and airports, and apart from that, it was included the proximity to tourist centers due to the increase in tourism in the city of Chachapoyas.

2.4. Software, Base Cartography, and Satellite Material. The cartographic data included maps of the 14 subcriteria, which included physical, environmental, and socioeconomic criteria. The thematic maps, based on vector and raster formats, were generated in ArcGIS 10.5, QGIS 3.10, Google Earth Pro 7.3, and Google Earth Engine (GEE). All maps were standardized to raster format with a spatial resolution of $30 \mathrm{~m}$.
The altitude and slope subcriteria were generated in ArcGIS from the digital elevation model (DEM ALOS PALSAR, $12.5 \mathrm{~m}$ ), downloaded from the Distributed Active Archive Center (DAAC) of the Alaska Satellite Installation (https://search.asf.alaska.edu/\#/). The soil texture was generated based on the layers of the sand, silt, and clay content of the global soil data system SoilGrids (https://soilgrids.org/ ) [52]. From SoilGrids, layers of three depths (0-5, 5-10, and $10-15 \mathrm{~cm}$ ) were averaged, with a spatial resolution of $250 \mathrm{~m}$. The geological faults and types of geology subcriteria were obtained from the National Geological Chart $13 h$ (scale 1 : 50 000) of the Geological, Mining, and Metallurgical Institute (Instituto Geológico, Minero y MetalúrgicoINGEMMET) [53]. The rainfall and temperature were 


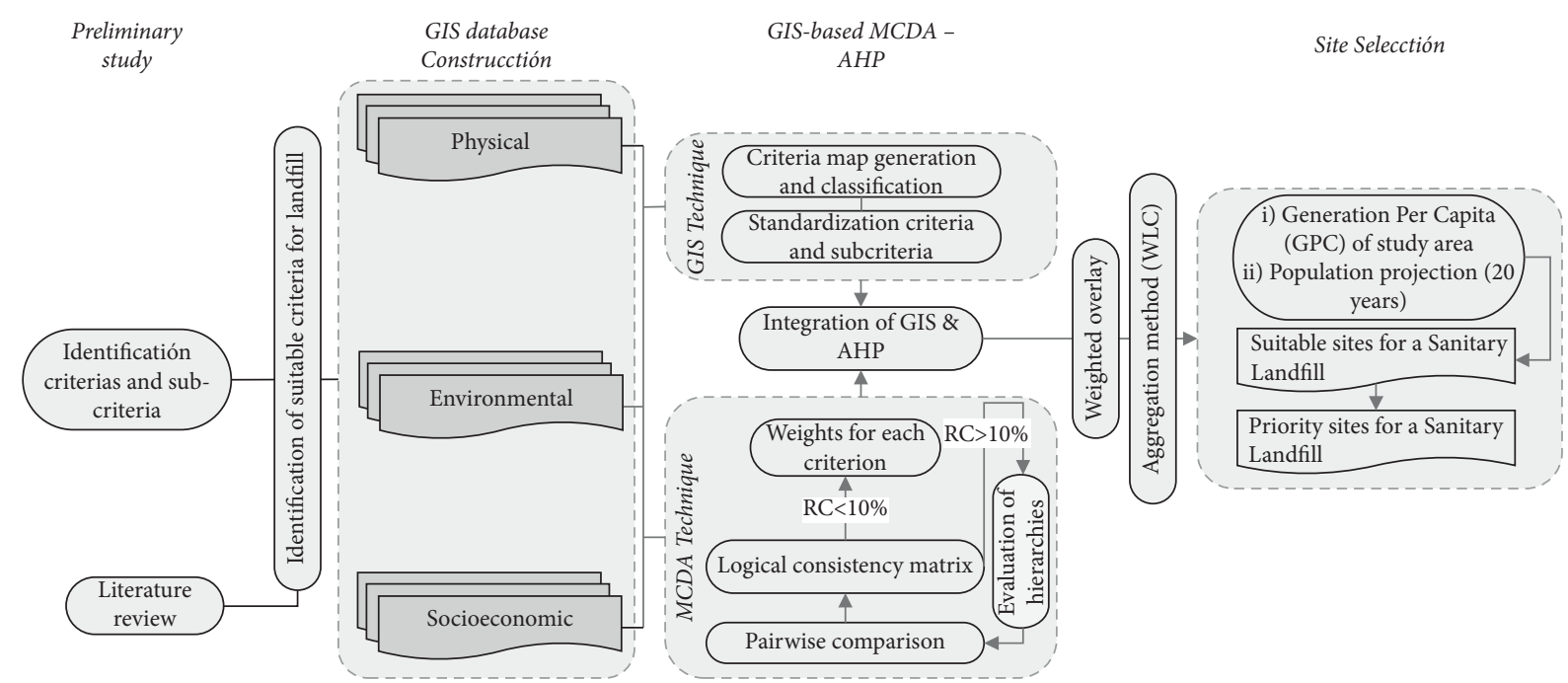

FIGURE 2: Methodological flowchart for determining suitable landfill sites.

downloaded to the WorldClim Climate Geodatabase version 2 (http://worldclim.org), with a spatial resolution of 30 seconds $(\sim 1 \mathrm{~km})$ [54].

The rivers of the National Charter $13 \mathrm{~h}$ (scale $1: 100$ 000) of the National Geographic Institute (Instituto Geográfico Nacional-IGN), downloaded from the website of the Ministry of Education (Ministerio de Educación-MINEDU), were used [55] and updated by manual mapping in Google Earth Pro. The LULC was generated in GEE with Sentinel 2B satellite images (ID =COPERNICUS/S2_SR), which were filtered with a cloud percentage of $13.3 \%$ in the period from 1 July 2019 to 6 June 2020. The average mosaic, with a cloud mask, was classified by a random forest (RF) algorithm and 102 training points in five classes (water, urban area, grasslands, forest, and scrubland) [56]. The LULC classification obtained an overall accuracy of 0.83 based on 45 verification points. In addition, the PNAs were updated in 2020 by the National Service of Natural Areas Protected by the State (Servicio Nacional de Áreas Naturales Protegidas por el Estado-SERNANP) [57].

The road layer was obtained from the Ministry of Transport and Communications (MTC) [58] and was updated by manual mapping in Google Earth Pro. Similarly, by manual digitization, tourist sites, urban areas, and airports were identified.

\subsection{Standardization of Subcriteria Layers Using Suitability} Thresholds. The layers of each subcriterion were standardized through reclassification, where a codification of land suitability alternatives was generated under thresholds that were determined by a literature review [59] (Table 1). The subcriteria were reclassified and scored in four alternatives: unsuitable $\left(S_{1}\right)$, marginally suitable $\left(S_{2}\right)$, moderately suitable $\left(S_{3}\right)$, and highly suitable $\left(S_{4}\right)$. Additionally, the alternative of restricted territory $\left(S_{0}\right)$, which includes the urban territory, the airport, and, additionally, the PNAs, is included in the analysis.
2.6. Hierarchical Process Analysis (AHP). The MCDA facilitates the structure, design, evaluation, and prioritization of alternatives in decision problems, and the AHP is one of the most commonly used techniques by DMs and researchers [62]. The AHP generates a pairwise comparison matrix (PCM), and important weights for the subcriteria and criteria using a rating scale of 1 to 9 are obtained from a group of experts (Table 2) [63]. In addition, the subjectivity of the experts who complete the PCM can be evaluated through the consistency ratio (CR) $[6,64]$.

The CR was determined by dividing the consistency index (CI) of the matrix in question by the random index (RI) of a matrix with the same number of " $n$ " criteria (Table 3 ). If $\mathrm{CR} \leq 10 \%$, the degree of consistency is satisfactory, while if CR $>10 \%$, the PCM is inconsistent and must be revised [6]. The CI serves as a measure of the logical inconsistency of the evaluation of experts during pairwise comparisons of criteria [65]. CI is calculated according to the order of the matrix $(n \times n)$ so that the greatest eigenvalue $(\lambda \max )$ is always greater than or equal to the number of rows and columns:

$$
\mathrm{CI}=\frac{(\lambda \max -n)}{(n-1)}
$$

2.7. Generation of Submodels and Models of the Suitability of the Territory. With the standardized subcriteria and their respective weights of importance, weighted linear combination (WLC) was applied [66]. Raster layers were integrated for each hierarchical group (Figure 3 ) to generate submodels for physical, environmental, and socioeconomic suitability. By integrating submodels, the final suitability model was obtained.

2.8. Prioritization of Highly Suitable Candidate Landfill Sites. The areas of the highly suitable $\left(S_{4}\right)$ polygons in the final suitability map were calculated and compared with the 


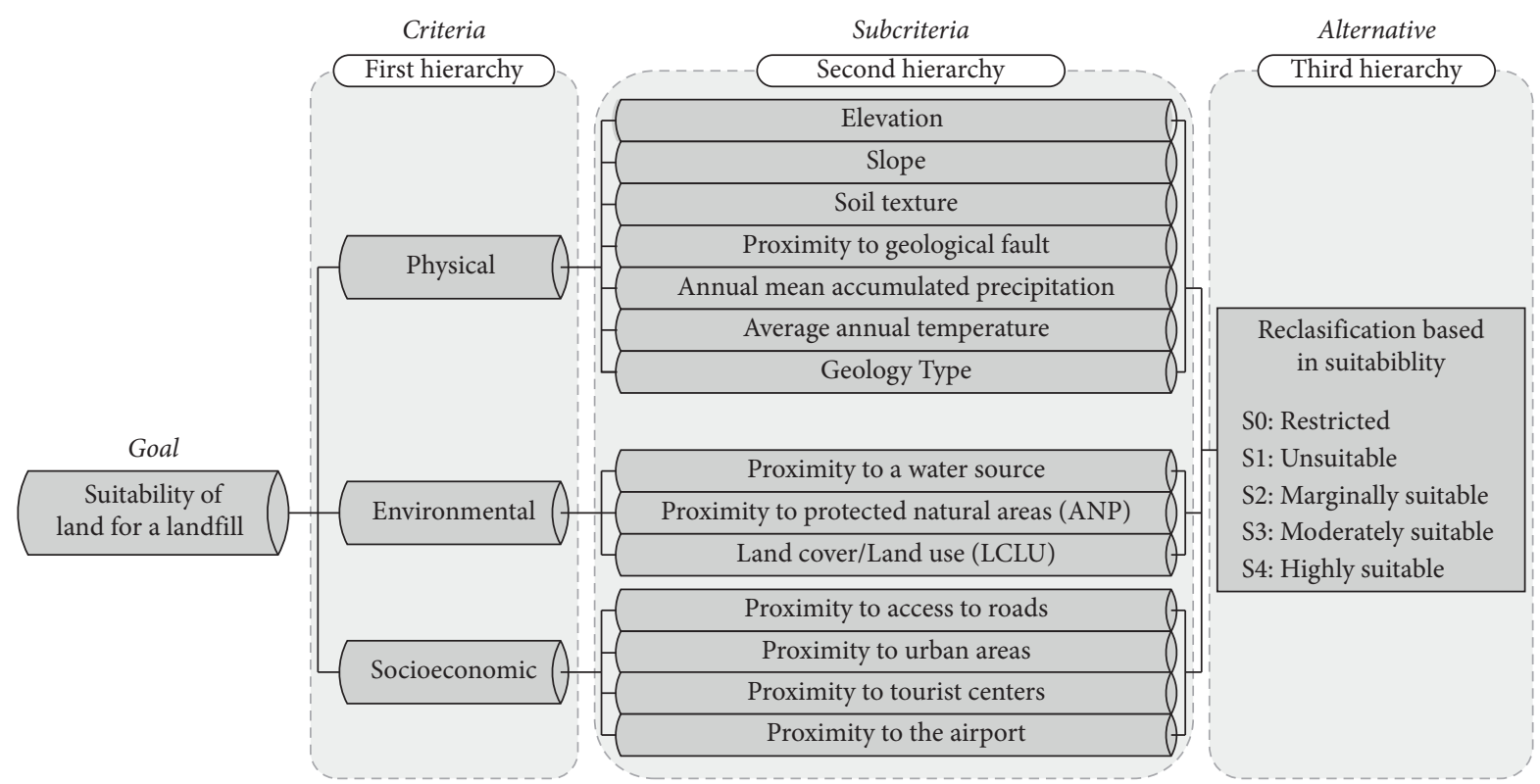

FIGURE 3: Hierarchical structure of the criteria and subcriteria considered in the analysis of the suitability of sites in the territory for a landfill.

minimum area required for the disposal of the MSW generated by the population of Chachapoyas. The minimum area was calculated with a projection of 20 years (2040) to prioritize and ensure the useful life of the landfill. For this calculation, the procedures of MINAM [51, 67] and Silveira and Gonçalves [27] were followed. Table 4 shows the data and equations used to estimate the minimum area for the landfill of the study area.

In addition, the shape of the highly suitable $\left(S_{4}\right)$ polygons was analyzed with the compactness coefficient $(K c)$ so that polygons with more regular shapes could be chosen [70]. The $K c$ was calculated from the perimeter $(P)$ and the area $(A)$ of each polygon (Equation (2)). Values of $K c$ close to 1 indicate that the polygons resemble a circle; when the values approach 1.75 , the polygons tend to be elongated, and values greater than 2 indicate irregular polygons [71].

$$
K c=\frac{P}{2 \sqrt{\pi A}}
$$

Finally, to validate the highly suitable sites $\left(S_{4}\right)$ meeting the requirements of area and shape, photogrammetric flights were performed with a Phantom 4 RTK drone.

\section{Results and Discussion}

3.1. Weights of Importance for Criteria and Subcriteria. The weights of the average importance of each criterion and subcriterion are shown in Table 5. These weights were determined by a panel of seven experts, which included local DMs and landfill specialists. The coherence index (CR) was $<10 \%$, physical (7.6\%), environmental (8.2\%), socioeconomic (5.2\%), and final model (5.2\%), thus allowing the establishment of importance weights. The subcriteria of greatest importance with respect to their hierarchical group were the slope $(22.76 \%)$, LULC $(47.10 \%)$, and proximity to urban areas $(30.1 \%)$, while those of less importance were the rainfall $(8.81 \%)$, proximity to a water source $(21.80 \%)$, and proximity to access to roads $(20.2 \%)$.

3.2. Maps of Subcriteria Generated according to Thresholds of Suitability of the Territory. Figure 4 shows the maps reclassified according to suitability thresholds (Table 1) of the physical, environmental, and socioeconomic subcriteria. In all subcriteria, $7.7 \%\left(14.21 \mathrm{~km}^{2}\right)$ of the study area was restricted $\left(S_{0}\right)$, corresponding to urban areas, the airport, and the PNAs. The subcriteria that had the most highly suitable area $\left(S_{4}\right)$ with respect to their hierarchical group were the elevation $(66.1 \%)$, proximity to PNA $(71.0 \%)$, and proximity to tourist centers $(69.1 \%)$ (Table 6). Those with greater "unsuitable" areas were the slope $(16.4 \%)$, proximity to a water source $(36.2 \%)$, and proximity to access to roads $(27.5 \%)$. Hence, the proximity to PNAs is the subcriterion that had the least impact on the landfill selection site; nevertheless, the proximity to a water source is the subcriterion that restricted the territory the most.

3.3. Submodel and Final Model Suitability Maps. Figure 5 shows the maps of the physical, environmental, and socioeconomic suitability submodels, which reached a degree of "highly suitable" in 4.5\% $\left(9.04 \mathrm{~km}^{2}\right), 6.0 \%\left(12.03 \mathrm{~km}^{2}\right)$, and $15.2 \%\left(30.40 \mathrm{~km}^{2}\right)$ of the study area, respectively (Table 7).

Figure 6 shows the final suitability map. Of the territory of Chachapoyas and Huancas districts, $0.9 \%\left(1.71 \mathrm{~km}^{2}\right)$, $71.1 \%\left(141.89 \mathrm{~km}^{2}\right), 21.0 \%\left(41.86 \mathrm{~km}^{2}\right)$, and $0.0 \%$ have highly suitable, moderately suitable, marginally suitable, and unsuitable conditions, respectively, for a landfill site. The highly suitable sites were in NW from Chachapoyas city, in the territory of Huancas district. 
TABLE 1: Suitability thresholds of the subcriteria to model the suitability of areas in the territory of Chachapoyas and Huancas (NW Peru) for landfills.

\begin{tabular}{|c|c|c|c|c|c|}
\hline Criteria/subcriteria & Unsuitable $\left(S_{1}\right)$ & Marginally suitable $\left(S_{2}\right)$ & $\begin{array}{c}\text { Moderately suitable } \\
\left(\mathrm{S}_{3}\right)\end{array}$ & $\begin{array}{l}\text { Highly suitable } \\
\left(S_{4}\right) \\
\end{array}$ & $\begin{array}{l}\text { Adapted } \\
\text { from }\end{array}$ \\
\hline \multicolumn{6}{|c|}{ Physical } \\
\hline Elevation (m.a.s.l) & $750-1000 ;>3200$ & $2800-3200$ & $1000-2000$ & $2000-2800$ & [35] \\
\hline Slope $(\%)$ & $>35$ & $25-35$ & $15-25$ & $0-15$ & {$[49,59,60]$} \\
\hline Soil texture ${ }^{1}$ & $\begin{array}{l}\text { L, SaL, SiL, Sa, } \\
\text { SaC }\end{array}$ & CL, CSiL & $\mathrm{CSi}, \mathrm{Si}$ & $\mathrm{C}$ & [9] \\
\hline $\begin{array}{l}\text { Proximity to geological } \\
\text { fault }(\mathrm{km})\end{array}$ & $<0.3$ & $0.3-1$ & $1-2$ & $>2$ & {$[18,33,49]$} \\
\hline $\begin{array}{l}\text { Mean annual rainfall } \\
(\mathrm{mm})\end{array}$ & $>2450$ & $1200-2450$ & $400-1200$ & $<400$ & {$[36]$} \\
\hline $\begin{array}{l}\text { Average annual } \\
\text { temperature }\left({ }^{\circ} \mathrm{C}\right)\end{array}$ & $<11$ & $11-14$ & $14-17$ & $17-21$ & {$[49]$} \\
\hline Geology type ${ }^{2}$ & $\mathrm{Ci}-\mathrm{a}, \mathrm{Q}-\mathrm{d}$ & $\begin{array}{c}\text { Chi-a, Tr-ch, Js-s, N-i, Chi-c, Q-al, } \\
\text { Jms-c, Ps-m }\end{array}$ & Ki-g, Q-co & Ki-ch, Ks-p & {$[17]$} \\
\hline \multicolumn{6}{|c|}{ Environmental } \\
\hline $\begin{array}{l}\text { Proximity to a water } \\
\text { source }(\mathrm{km})\end{array}$ & $<0.3$ & $0.3-0.5$ & $0.5-1$ & $>1$ & {$[51]$} \\
\hline Proximity to PNA $(\mathrm{km})$ & - & $0-0.5$ & $0.5-2$ & $>2$ & {$[7,60]$} \\
\hline LULC & $\begin{array}{l}\text { Forest; water } \\
\text { bodies }\end{array}$ & Scrublands & Pastures and crops & Bare soil & {$[16,18,60]$} \\
\hline \multicolumn{6}{|c|}{ Socioeconomic } \\
\hline $\begin{array}{l}\text { Proximity to access to } \\
\text { roads }(\mathrm{km})\end{array}$ & $<0.2>2$ & $1-2$ & $0.5-1$ & $0.2-0.5$ & {$[59,61]$} \\
\hline $\begin{array}{l}\text { Proximity to urban areas } \\
(\mathrm{km})\end{array}$ & $<0.5$ & $0.5-1$ & $1-2$ & $>2$ & {$[51]$} \\
\hline $\begin{array}{l}\text { Proximity to tourist } \\
\text { centers }(\mathrm{km})\end{array}$ & $<0.5$ & $0.5-1$ & $1-2$ & $>2$ & {$[50]$} \\
\hline $\begin{array}{l}\text { Proximity to the airport } \\
(\mathrm{km})\end{array}$ & $<3$ & $3-3.5$ & $3.5-4.5$ & $>4.5$ & {$[51,60]$} \\
\hline
\end{tabular}

${ }^{1}$ L: loam; SaL: sandy loam; SiL: silty loam; CL: clay loam; CSiL: clay-silt loam; SaC: sand clay; Sa: sand; C: clay; CSi: clay silt; LSa: loam sand; Si: silt. ${ }^{2}$ ki-g: Gollanquizga; Ji-a: Aramachasy; Tr-ch: Cahmbara; Js-s: Forma. Sayaraquillo; Ki-ch: Chulec; N-i: Form. Inguilpata; Ji-c: Condorsinga; Q-al: Deposito aluvial; Jms-c: Form. Corontacocha; Q-co: Deposicos coluviales; Q-d: Depósitos de deslizaminetos; Ps-m: Grupo Mito; Ks-p: Gpto Pulluicana; Ci-a: Grupo Ambo.

TABLe 2: Analytical hierarchy process evaluation scale.

\begin{tabular}{lc}
\hline Numerical value of $P_{i j}$ & Value definition \\
\hline 1 & Equal importance of $i$ and $j$ \\
3 & Moderate importance of $i$ over $j$ \\
5 & Strong importance of $i$ over $j$ \\
7 & Very strong importance of $i$ over $j$ \\
9 & Extreme importance of $i$ over $j$ \\
$2,4,6,8$ & Intermediate values \\
\hline
\end{tabular}

3.4. Candidate Sites Highly Suitable for Landfills. The minimum area required for a landfill, for a population and generation of MSW projected to 2040, was calculated to be 3.2 ha (Table 8 ). Twelve highly suitable polygons with areas $\geq 3.2$ ha were counted, of which three had $K c<1.75$ (A1-A3), three had $K c$ between 1.75-2 (A4, A9, and A11), and the remaining $K c>2$ (A5-A8, A10, and A12) (Figure 6).

Sites A1 (6.66 ha and $K c=1.37)$, A2 (7.65 ha and $K c=1.64)$, A3 (24.48 ha and $K c=1.49)$, A4 (3.42 ha and $K c=1.82)$, A5 (11.43 ha and $K c=2.04)$, A6 (6.75 ha and $K c=2.59)$, A7 (7.83 ha and $K c=3.12)$, A8 (6.66 ha and $K c=2.6)$, A9 (3.6 ha and $K c=1.95), \mathrm{A} 10$ (3.33 ha and $K c=2.58), \mathrm{A} 11$ (8.01 ha and $K c=1.90)$, and A12 (4.05 ha and $K c=2.34)$ were used for the validation process. Images from the SAS Planet 200606.10075 platform were used, as shown in Figure 7.

3.5. Discussion. The inadequate selection for landfill sites location has negative economic, environmental, and ecological impacts [72] and poses risks to human health [51, 73]. A landfill site as a method of solid waste disposal is still accepted, especially in developing countries [40]. However, it requires strict control of gas, leachate, and fire occurrence. In this context, we highlight the importance of conducting future risk assessment studies of landfills [38].

The use of the integrated methodology MCDA-AHP and GIS-RS has been a successful tool for finding the optimal landfill site location $[13,21,26,30,32,41,74]$. Unfortunately, in Peru, there is a serious lack of this type of methodology [51] and an adequate location of landfills [12]. In this context, this study presents a methodological framework that can be replicated for other areas of Peru since the requirements established by MINAM were included [51].

In contrast to previous studies $[6,7,13,16,40,69,75]$, except for Chamchali et al. [28] and Sumathi [39], a greater number of subcriteria were employed (26 and 17), 
TABLe 3: Value of the random index for each " $n$ ".

\begin{tabular}{|c|c|c|c|c|c|c|c|c|c|c|c|c|c|}
\hline$n$ & 1 & 2 & 3 & 4 & 5 & 6 & 7 & 8 & 9 & 10 & 11 & 12 & 13 \\
\hline RI & 0 & 0 & 0.525 & 0.882 & 1.115 & 1.252 & 1.341 & 1.404 & 1.452 & 1.484 & 1.513 & 1.535 & 1.555 \\
\hline
\end{tabular}

TABle 4: Data for estimating the minimum area for the landfill.

\begin{tabular}{|c|c|c|}
\hline Description & Value/equation & Based on \\
\hline Generation per capita (GPC) & $0.435 \mathrm{~kg} / \mathrm{ha}$. day & [45] \\
\hline Density $(\rho)$ & $1010.98 \mathrm{~kg} / \mathrm{m}^{3}$ & {$[45]$} \\
\hline Population growth rate $(d)$ & $3.3 \%$ & {$[27]$} \\
\hline Maximum height of the landfill $(h)$ & $6.00 \mathrm{~m}$ & [27] \\
\hline Service life (SL) & 20 años & {$[27]$} \\
\hline City population by 2040 & $\mathrm{Pop}_{2040}=\mathrm{P} 0 \times(1+d)^{t} ; t=\mathrm{SL}$ & [27] \\
\hline Amount of municipal solid waste (MSW) generated in a day & $Q_{2040}=$ Pop $_{2040} \times \mathrm{GPC}$ & {$[27,68]$} \\
\hline Total volume of MSW generated in one day & $V_{\text {diario }}=Q_{2040 /} \rho$ & {$[27,69]$} \\
\hline Total volume of MSW generated in 20 years & $V_{2040}=V_{\text {diario }} \times 365 \times 20$ & {$[27,70]$} \\
\hline Minimum area for a landfill & $A_{\min }=V_{2040 /} h$ & [27] \\
\hline
\end{tabular}

TABLE 5: Weights of importance for the criteria and subcriteria for modeling the suitability of the territory of Chachapoyas and Huancas, NW Peru for a landfill.

\begin{tabular}{|c|c|c|c|c|c|c|}
\hline Goal & Criterion & Weight (\%) & Ranking & Subcriterion & Weight (\%) & Ranking \\
\hline \multirow{14}{*}{ Suitability for a landfill site } & \multirow{8}{*}{ Physical } & \multirow{7}{*}{33.2} & \multirow{7}{*}{2} & Elevation & 13.2 & 4 \\
\hline & & & & Slope & 22.8 & 1 \\
\hline & & & & Soil texture & 9.0 & 6 \\
\hline & & & & Proximity to geological fault & 16.0 & 3 \\
\hline & & & & Mean annual rainfall & 8.8 & 7 \\
\hline & & & & Average annual temperature & 10.7 & 5 \\
\hline & & & & Geology type & 19.4 & 2 \\
\hline & & \multirow{3}{*}{37.0} & \multirow{3}{*}{1} & Proximity to a water source & 21.8 & 3 \\
\hline & \multirow[t]{2}{*}{ Environmental } & & & Proximity to PNA & 31.1 & 2 \\
\hline & & & & LULC & 47.1 & 1 \\
\hline & \multirow{4}{*}{ Socioeconomic } & \multirow{4}{*}{29.8} & \multirow{4}{*}{3} & Proximity to access to roads & 20.2 & 4 \\
\hline & & & & Proximity to urban areas & 30.1 & 1 \\
\hline & & & & Proximity to tourist centers & 23.5 & 3 \\
\hline & & & & Proximity to the airport & 26.1 & 2 \\
\hline
\end{tabular}

respectively. However, in this type of study, the number of subcriteria depends on the focus of the study and the availability of spatial data. For example, Rezaeisabzevar [7] used criteria such as noise, reduction in property value, odor, and negative aesthetic impacts. Indeed, these criteria were not considered in our study since in Peru, and specifically in the Amazonas region, there are scarce spatial data of physical, environmental, and socioeconomic criteria at the local scale as described by Yunis et al. [66].

For the Chachapoyas-Huancas community, the environmental criteria $(37.0 \%)$ are the most important, followed by the physical (32.2\%) and socioeconomic (29.8\%) criteria. For Karimi et al. [33], who considered fewer physical subcriteria, the environmental criteria are more important than the economic criteria. However, for Ding et al. [67], the socioeconomic criteria are more important than the environmental criteria.

The differences in the importance of the criteria are explained by the number of and differences in subcriteria used, as well as the local reality and the experience of the experts.
In the physical subcriteria, the slope (22.3\%) and geology (19.4\%) were the most important. However, for Sener et al. [35], the slope is less important than the geology. Geology is of great importance for the location of suitable sites in landfills because soil formation directly affects the costs of excavation $[49,61]$. In addition, along with the slope, the geology minimizes or facilitates groundwater contamination due to infiltration $[13,61]$.

In the environmental criteria, LULC (47.1\%) and the distance to PNA (31.1\%) were the most important. This tendency was probably due to conservationist characteristics in the panel of experts. Moreira et al. [69], Kamiri et al. [33], Şener [35], Barzehkar et al. [76], and Fides [77] highlight the importance of PNAs as an environmental criterion. In addition, as in previous studies $[6,26,51,68]$, the distance to water resources was considered to avoid future leachates as pollutants [7]. Although MINAM [51] emphasizes the importance of water sources in the determination of a landfill location, our experts did not place strong importance on this criterion because within the study area, the water sources are small and seasonal and have low drainage density. 


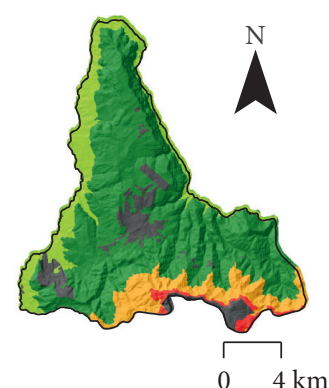

Suitability

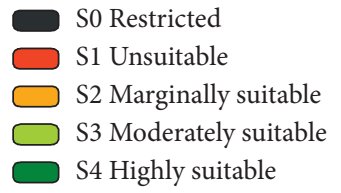

(a)

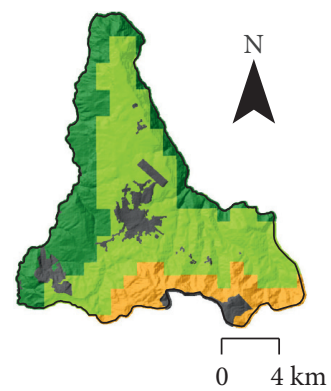

Suitability

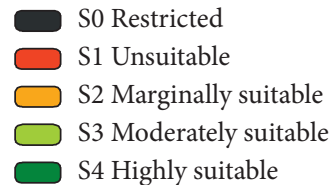

(f)

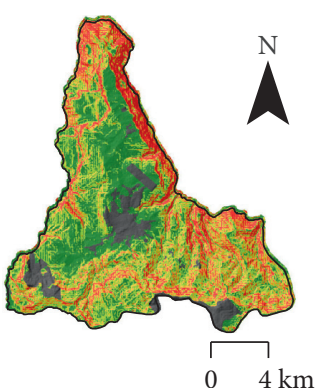

Suitability

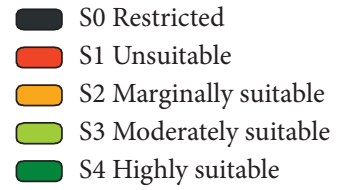

(b)

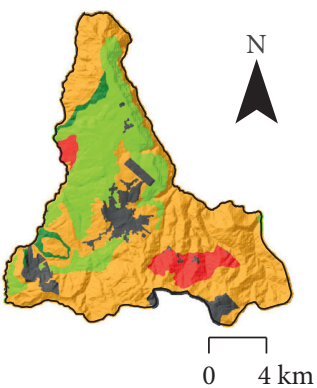

Suitability

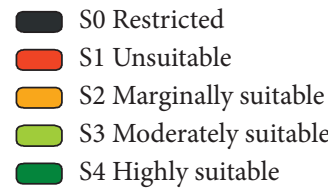

(g)

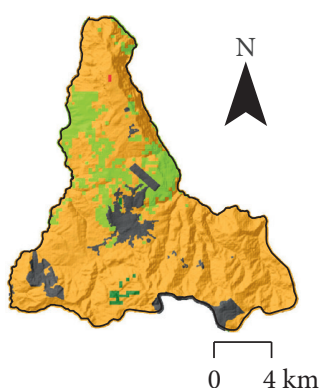

Suitability

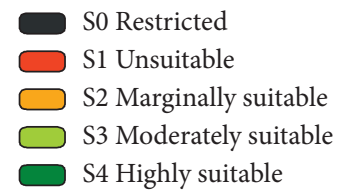

(c)

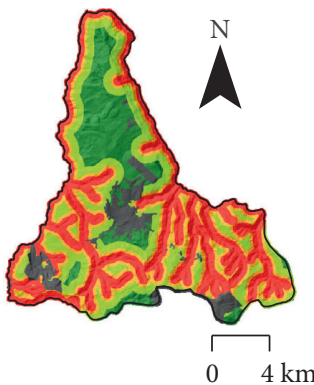

Suitability

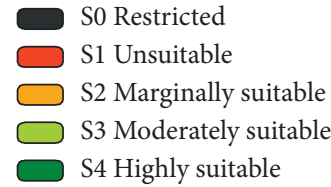

(h)

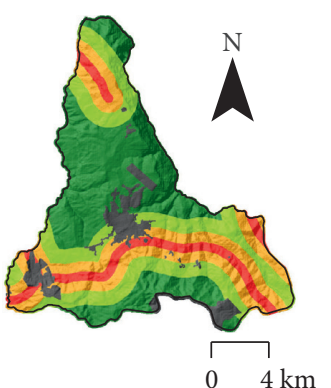

Suitability

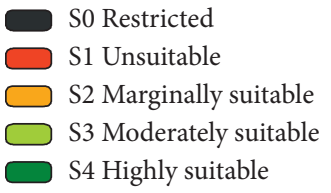

(d)

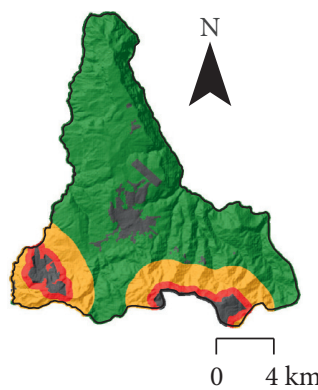

Suitability

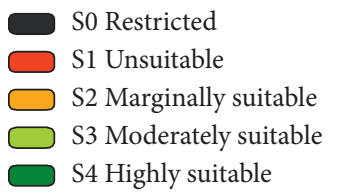

(i)

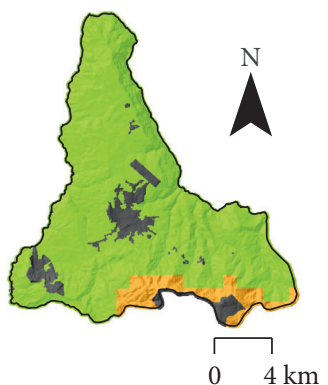

Suitability

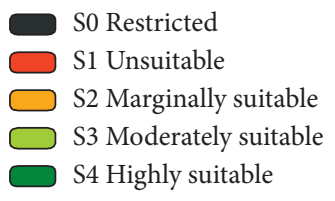

(e)

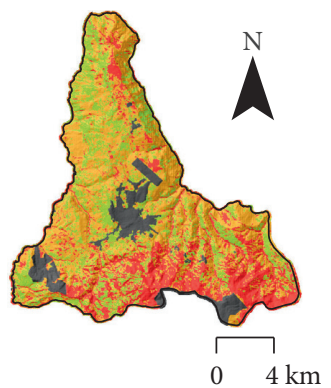

Suitability

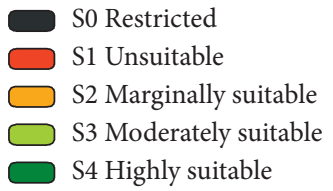

(j)
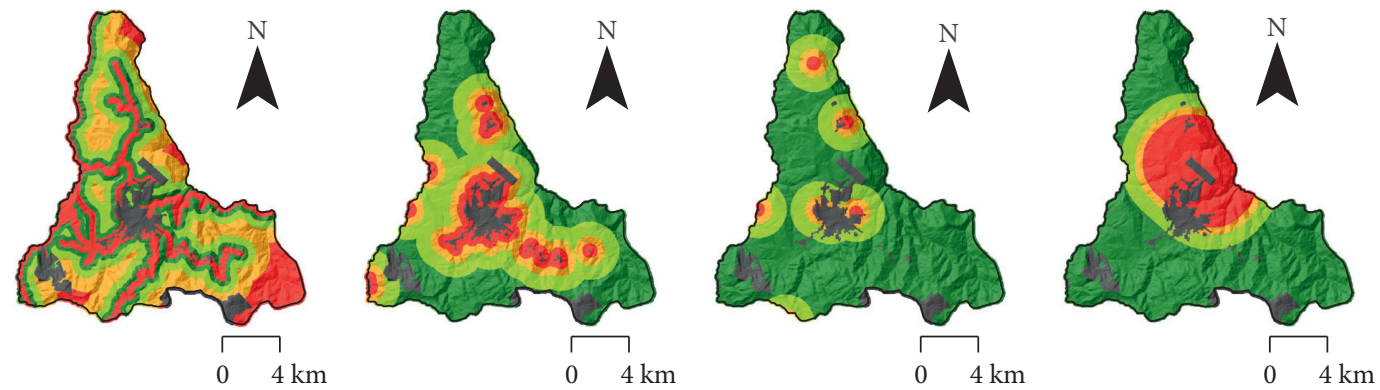

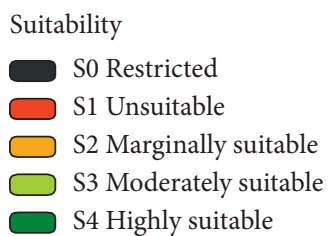

(k)

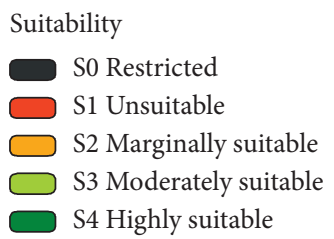

(1)

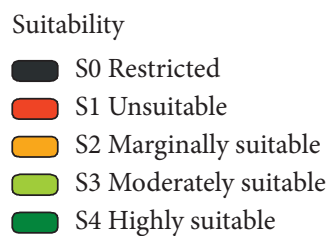

(m)

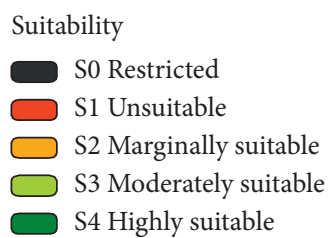

(n)

Figure 4: Maps of suitability subcriteria under the thresholds for suitable sites to locate a Chachapoyas landfill, NW Peru. (a) Elevation. (b) Slope. (c) Soil texture. (d) Proximity to geological fault. (e) Average annual precipitation. (f) Average annual temperature. (g) Geology type. (h) Proximity to a water source. (i) Protected natural areas (PNA). (j) Land use/land cover. (k) Proximity to access to roads. (l) Proximity to urban areas. (m) Proximity to tourist centers. (n) Proximity to the airport. 
TABLE 6: Areas according to suitability levels for each subcriterion for the analysis of the suitability of potential landfill sites in Chachapoyas and Huancas, NW Peru.

\begin{tabular}{|c|c|c|c|c|c|c|c|c|}
\hline \multirow[t]{2}{*}{ Subcriterion } & \multicolumn{2}{|c|}{ Unsuitable $\left(S_{0}\right)$} & \multicolumn{2}{|c|}{$\begin{array}{l}\text { Marginally } \\
\text { suitable }\left(S_{2}\right)\end{array}$} & \multicolumn{2}{|c|}{$\begin{array}{l}\text { Moderately } \\
\text { suitable }\left(S_{3}\right)\end{array}$} & \multicolumn{2}{|c|}{$\begin{array}{c}\text { Highly suitable } \\
\left(S_{4}\right)\end{array}$} \\
\hline & $\mathrm{km}^{2}$ & $\%$ & $\mathrm{~km}^{2}$ & $\%$ & $\mathrm{~km}^{2}$ & $\%$ & $\mathrm{~km}^{2}$ & $\%$ \\
\hline Elevation & 3.85 & 1.9 & 20.82 & 10.4 & 28.84 & 14.4 & 131.95 & 66.1 \\
\hline Slope & 32.73 & 16.4 & 41.31 & 20.7 & 53.26 & 26.7 & 58.16 & 29.1 \\
\hline Soil texture & 17.10 & 0.1 & 40.25 & 78.8 & 49.23 & 13.4 & 78.89 & 0.6 \\
\hline Proximity to geological fault & 0.00 & 8.6 & 15.50 & 20.2 & 169.96 & 24.7 & 0.00 & 39.5 \\
\hline Mean annual rainfall & 0.00 & 0.0 & 25.89 & 7.8 & 105.32 & 85.1 & 54.25 & 0.0 \\
\hline Average annual temperature & 12.12 & 0.0 & 116.56 & 13.0 & 52.51 & 52.7 & 4.28 & 27.2 \\
\hline Geology type & 3.85 & 6.1 & 20.82 & 58.4 & 28.84 & 26.3 & 131.95 & 2.1 \\
\hline Proximity to a water source & 72.29 & 36.2 & 34.65 & 17.4 & 44.23 & 22.2 & 34.30 & 17.2 \\
\hline Proximity to PNA & 11.31 & 5.7 & 32.44 & 16.2 & 0.00 & 0.0 & 141.72 & 71.0 \\
\hline LULC & 49.89 & 25.0 & 85.03 & 42.6 & 50.55 & 25.3 & 0.00 & 0.0 \\
\hline Proximity to access to roads & 54.87 & 27.5 & 43.40 & 21.7 & 46.79 & 23.4 & 40.41 & 20.2 \\
\hline Proximity to urban areas & 24.66 & 12.3 & 28.09 & 14.1 & 57.64 & 28.9 & 75.08 & 37.6 \\
\hline Proximity to tourist centers & 2.70 & 1.4 & 9.41 & 4.7 & 35.40 & 17.7 & 137.96 & 69.1 \\
\hline Proximity to the airport & 35.09 & 17.6 & 7.74 & 3.9 & 19.47 & 9.8 & 123.17 & 61.7 \\
\hline
\end{tabular}

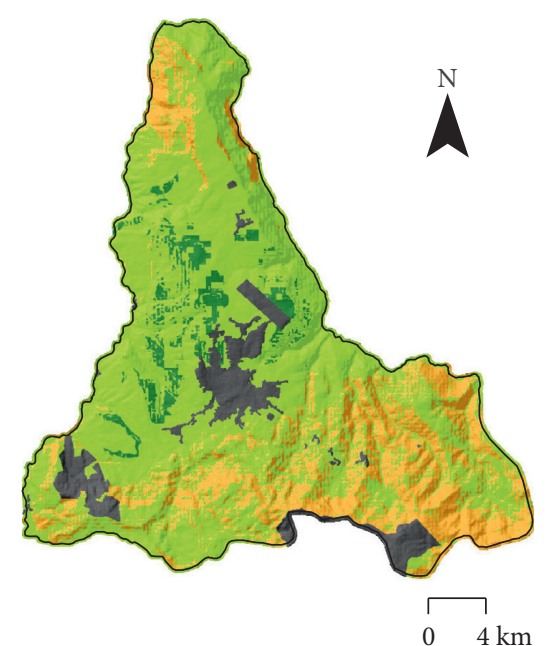

S0 Restricted

S1 Unsuitable

S2 Marginally suitable

S3 Moderately suitable

S4 Highly suitable

(a)
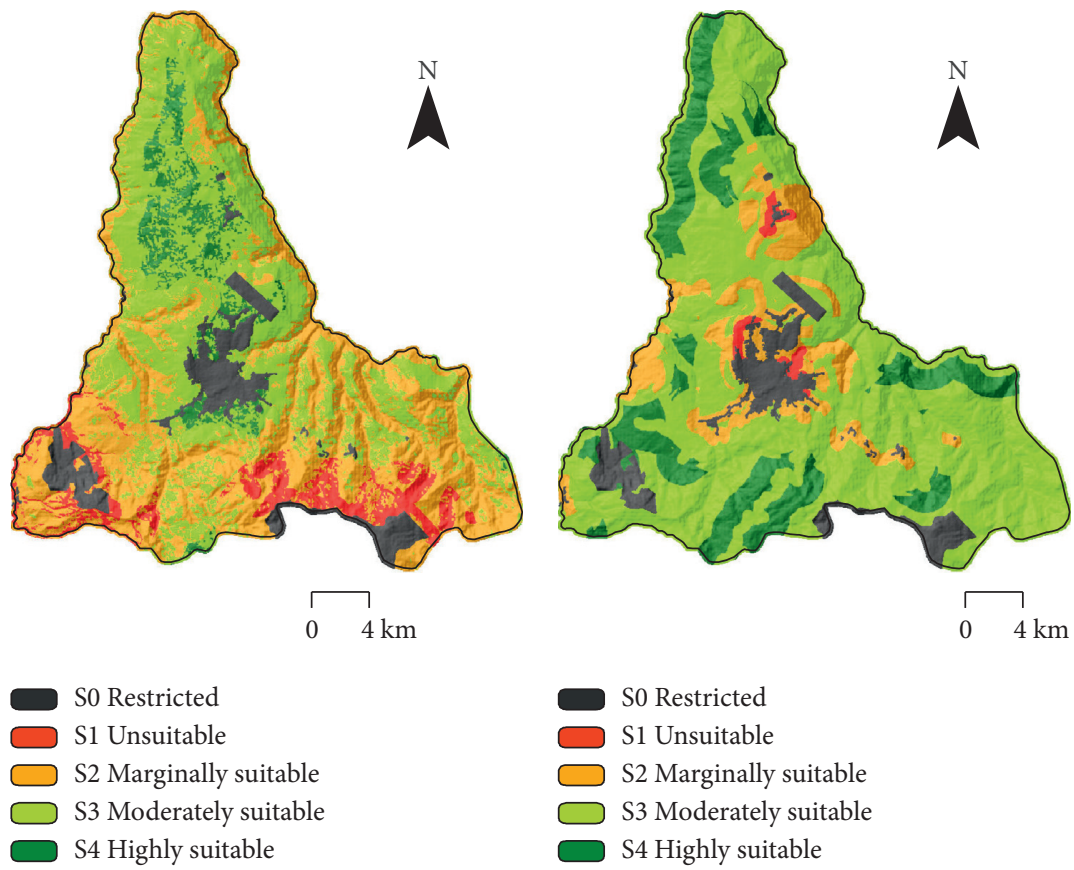

(b)
S0 Restricted

S1 Unsuitable

S2 Marginally suitable

S3 Moderately suitable

S4 Highly suitable

(c)

Figure 5: Maps of the physical (a), environmental (b), and socioeconomic (c) suitability submodels.

TABLE 7: Criteria surfaces and restrictions for each suitability alternative for a future landfill.

\begin{tabular}{lccccccc}
\hline \multirow{2}{*}{ Criterion } & \multicolumn{2}{c}{ Unsuitable $\left(S_{1}\right)$} & \multicolumn{2}{c}{ Marginally suitable } & \multicolumn{2}{c}{ Moderately suitable } & \multicolumn{2}{c}{ Highly suitable $\left(S_{4}\right)$} \\
& $\mathrm{km}^{2}$ & $\%$ & $\mathrm{~km}^{2}$ & $\%$ & $\mathrm{~km}^{2}$ & $\%$ & $\mathrm{~km}^{2}$ \\
\hline Physical & 0.01 & 0.0 & 44.74 & 22.4 & 131.67 & 65.9 & 9.04 \\
Environmental & 14.68 & 7.4 & 77.38 & 38.8 & 81.37 & 40.8 & 12.03 \\
Socioeconomic & 2.70 & 1.4 & 28.71 & 14.4 & 123.66 & 61.9 & 30.40 \\
Final suitability map & 14.21 & 7.1 & 0.00 & 0.0 & 41.86 & 21.0 & 14.0 \\
\hline
\end{tabular}




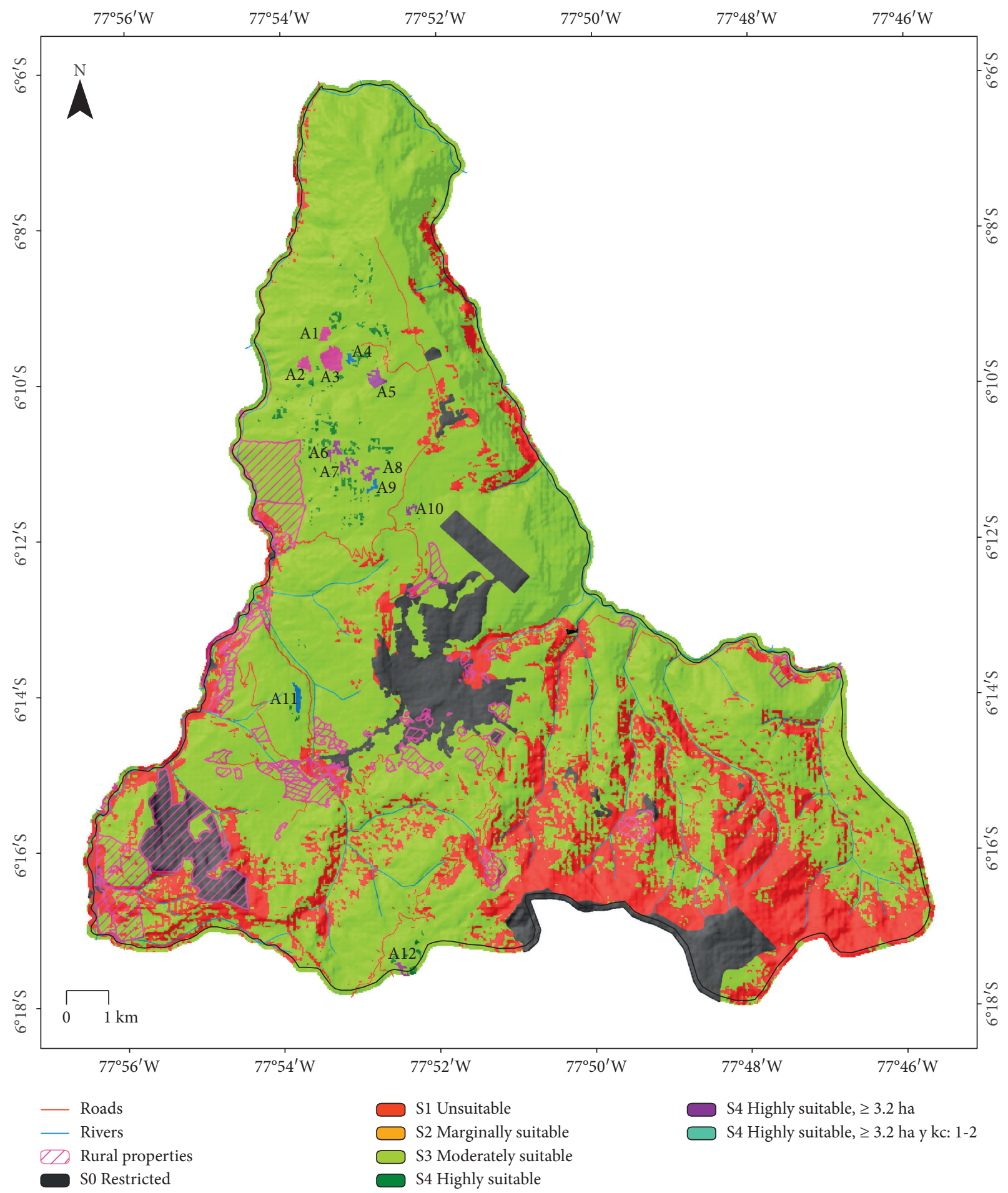

FIgURE 6: Suitability maps for potential sites for a Chachapoyas landfill, NW Peru.

TABLE 8: Estimation of the minimum area for a future landfill in Chachapoyas, NW Peru, estimated with a useful service life (SL) for 20 years.

\begin{tabular}{lr}
\hline Description & Result \\
\hline City population by 2040 & $61306.87 \mathrm{hab}$. \\
Amount of MSW generated in a day & $26668.49 \mathrm{~kg} / \mathrm{day}$ \\
Total volume of MSW generated in one day & $26.38 \mathrm{~m}^{3} / \mathrm{day}^{3}$ \\
Total volume of MSW generated in 20 years & $192565.5891 \mathrm{~m}^{3}$ \\
Minimum area for a landfill & $3.2 \mathrm{ha}$. \\
\hline
\end{tabular}



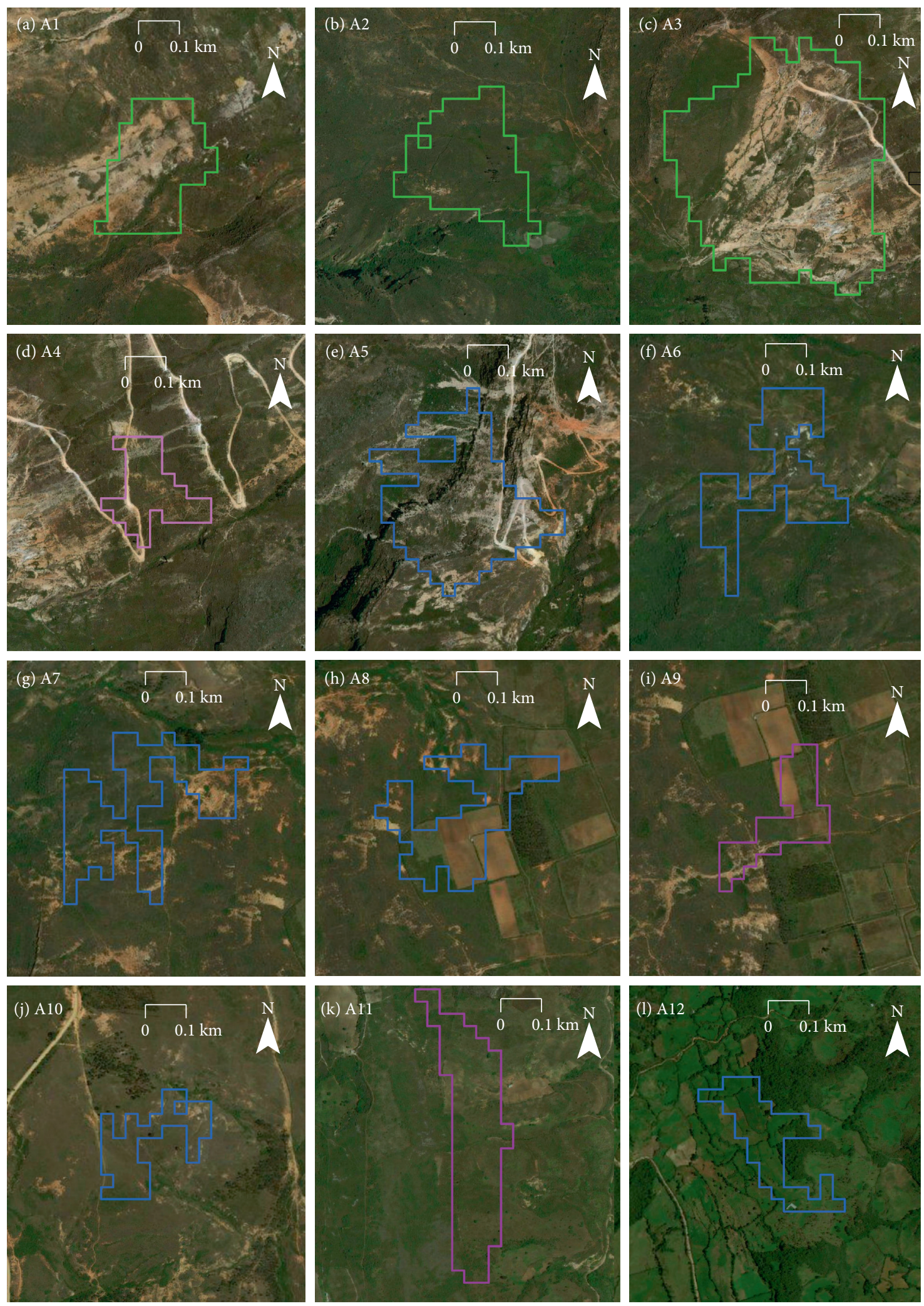

$\mathrm{I}(\mathrm{Kc}<1.75)$

II (Kc between 1.75-2)

III $(\mathrm{Kc}>2)$

Figure 7: Satellite view of highly suitable sites for landfills. (a) A1. (b) A2. (c) A3. (d) A4. (e) A5. (f) A6. (g) A7. (h) A8. (i) A9. (j) A10. (k) A11. (l) A12. 
The most important socioeconomic subcriteria are the proximity to urban areas $(30.1 \%)$ and the proximity to access to roads $(26.1 \%)$. Sener et al. $[35,78]$ highlight urban centers as the most important, while Mustafa and Bwadi [79] consider access to roads. In addition, as in Rezaeisabzevar et al. [7], the subcriterion of tourist proximity was considered because the study area contains historical and religious sites of cultural and tourist importance. On the other hand, landfills have a certain degree of attraction by birds [60], a reason to incorporate the proximity to the airport of Chachapoyas.

Twelve highly suitable sites were identified for the location of landfills that have the minimum area ( $\geq 3.2 \mathrm{ha}$ ) required for their operation until 2040. From these sites, three were selected that have a form factor $(K c \leq 1.75)$ that meets the design parameters. The minimum projected area analyses (see MINAM [80] and Silveira \& Gonçalves [27]) and form analysis (see Palacios [70]) facilitated the better selection of the site than previous studies that performed only AHP and GIS. However, for the final selection of a single site, detailed field studies should be carried out (soil, wind direction, and other parameters). Therefore, although the MCDA-AHP and GIS-RS studies are not definitive, they decrease the cost and time.

In a comparison of the final suitability model with the location of the OWDS "El Atajo," the latter does not meet the necessary requirements. Namely, MINAM [81] considers this site to be one of the 1585 environmental liabilities of Peru and through Ministerial Resolution [82] declared this site to be in a state of emergency. In addition, Mego et al. [47], based on physicochemical and microbiological analysis, concluded that El Atajo has a direct impact on water bodies and poses a high risk to the population because of pollutants.

The methodology used in this research integrates MCDA-AHP and GIS-RS for the analysis of the suitable areas in the territory for landfills and can be applied to other areas, with the necessary adjustments to their local conditions. These adjustments can include other detailed socioeconomic and environmental variables and other suitability methods, such as neural networks, machine learning, and fuzzy logic.

\section{Conclusions}

The assessment of the suitability of the territory to determine potential sites for a sanitary landfill in the ChachapoyasHuancas community had certain limitations. One of them was the low availability of cartographic data for the study area, which was overcome by updating and generating other data in order to have a greater number of sub-criteria for evaluating the territory (Table 1 ). In relation to improving the accuracy of the final suitability model in this study, further assessment is recommended based on criteria for sites with the best potential, alongside the considerations raised in this study (Table 4 ).

This study establishes an MCDA-AHP methodological framework based on GIS-RS to evaluate the optimal landfill sites. Seven physical subcriteria, three environmental subcriteria, and four socioeconomic subcriteria were considered. The study was supported by seven specialists that were DMs and experts through their assessment of the PCM criteria. Of the territory of Chachapoyas and Huancas districts, $\quad 0.9 \% \quad\left(1.71 \mathrm{~km}^{2}\right), \quad 71.1 \% \quad\left(141.89 \mathrm{~km}^{2}\right), \quad 21.0 \%$ $\left(41.86 \mathrm{~km}^{2}\right), 0.0 \%$, and $7.7 \%\left(14.21 \mathrm{~km}^{2}\right)$ have highly suitable, moderately suitable, marginally suitable, unsuitable, and restricted conditions, respectively, for a landfill site. Twelve highly suitable sites were identified, of which three were selected based on their area and form factor. These sites are the El Molino sector $(A 1=6.66 \mathrm{ha})$, Levanto highway $(A 2=7.65 \mathrm{ha})$, and Huancas $(A 3=24.48 \mathrm{ha})$.

This study will provide support for decision-making for suitable landfill sites selection; moreover, this research offers an opportunity to improve territorial planning and provides a management tool for public health.

\section{Data Availability}

The data used to support the findings of this study are available from the corresponding author upon request.

\section{Conflicts of Interest}

The authors declare that there are no conflicts of interest.

\section{Acknowledgments}

The authors acknowledge and appreciate the support of the Research Institute for Sustainable Development in Highland Forests (INDES-CES) of the National University Toribio Rodríguez de Mendoza de Amazonas (UNTRM) and also the support from the solid waste area of the Provincial Municipality of Chachapoyas (MPCH). This work was carried out with the support of the Public Investment Project GEOMATICA (SNIP No. 312235), executed by the Research Institute for Sustainable Development in Highland Forests (INDES-CES) of the National University Toribio Rodríguez de Mendoza de Amazonas (UNTRM).

\section{References}

[1] M. W. K. S. C. Ojeda, S. Lozano, and G. Quintero, "PeriodoEstacional: El caso de una ciudad mexicana," I Simp. Iberoam. Ing. Residuos, pp. 23-24, 2008.

[2] S. Kaza, L. C. Yao, P. Bhada-Tata, and F. Van Woerden, What a waste 2.0: Una instantánea global de la gestión de residuos sólidos hasta 2050, 2018.

[3] P. K. Dara and T. B. Reddy, "Municipal solid waste landfill sites selection for visakhapatnam city under vision 2020 using GIS and AHP," International Journal of Contemporary Research and Review, vol. 9, no. 6, pp. 20181-20194, 2018.

[4] A. Sáez and G. Urdaneta, "Omnia," Choice Reviews Online, vol. 44, no. 3, 2006.

[5] C. Zafra-Mejía and D. Romero-Torres, "Tendencias tecnológicas de depuración de lixiviados en rellenos sanitarios iberoamericanos," Revista Ingenierías Universidad de Medellín, vol. 18, no. 35, pp. 125-147, 2019.

[6] M. Uyan, "MSW landfill site selection by combining AHP with GIS for Konya, Turkey," Environmental Earth Sciences, vol. 71, no. 4, pp. 1629-1639, 2014. 
[7] Y. Rezaeisabzevar, A. Bazargan, and B. Zohourian, "Landfill site selection using multi criteria decision making: i," vol. 93, pp. 170-184, 2020.

[8] K. Noguera and J. Olivero-Verbel, "Los rellenos sanitarios en Latinoamerica: caso Colombiano," Rev. la Acad. Colomb. Ciencias Exactas, Físicas y Nat.vol. 34, no. 132, pp. 347-356, 2010.

[9] M. A. Alanbari, N. Al-Ansari, H. K. Jasim, and S. Knutsson, "Modeling landfill suitability based on GIS and multicriteria decision analysis: case study in Al-mahaweelqadaa," Natural Science, vol. 06, no. 11, pp. 828-851, 2014.

[10] OPS (Organización Panamericana de la Salud), Informe de la evaluación Regional del manejo de residuos sólidos urbanos en América Latina y el Caribe 2010, 2011. OPS-OMS, InterAmerican Development Bank, Washington, DC, USA, 2010.

[11] MEF (Ministerio de Economía y Finanzas), Guía para el cumplimiento de la Meta 3 del Programa de Incentivos a la Mejora de la Gestión Municipal 2020, MEF, Los Angeles, CA, USA, 2020.

[12] MINAM (Ministerio del Ambiente), Infraestructuras de disposición final de residuos sólidos - Listado de rellenos sanitarios en el Perú, MINAM, Lima, Perú, 2020, https://www.gob.pe/ institucion/minam/informes-publicaciones/279709-listadode-rellenos-sanitarios.

[13] S. P. Gbanie, P. B. Tengbe, J. S. Momoh, J. Medo, V. T. S. Kabba, and S. Kabba, "Modelling landfill location using geographic information systems (GIS) and multi-criteria decision analysis (MCDA): case study bo, southern Sierra Leone," Applied Geography, vol. 36, pp. 3-12, 2013.

[14] C. B. Karakuş, D. Demiroğlu, A. Çoban, and A. Ulutaş, "Evaluation of GIS-based multi-criteria decision-making methods for sanitary landfill site selection: the case of Sivas city, Turkey," Journal of Material Cycles and Waste Management, vol. 22, no. 1, pp. 254-272, 2020.

[15] D. Elena, D. Garza-requena, F. Rafael, and E. Carmen, "Los rellenos sanitarios: una alternativa para la disposición final de los residuos sólidos urbanos," Ciencia, vol. 6, no. 2, pp. 14-17, 2011.

[16] A. Barakat, A. Hilali, M. E. Baghdadi, and F. Touhami, "Landfill site selection with GIS-based multi-criteria evaluation technique. a case study in Béni Mellal-Khouribga Region, Morocco," Environmental Earth Sciences, vol. 76, no. 12, 2017.

[17] H. I. Mohammed, Z. Majid, and Y. B. Yamusa, "GIS based sanitary landfill suitability analysis for sustainable solid waste disposal," IOP Conference Series: Earth and Environmental Science, vol. 220, Article ID 012056, 2019.

[18] H. Khorsandi, A. Faramarzi, A. A. Aghapour, and S. J. Jafari, "Landfill site selection via integrating multi-criteria decision techniques with geographic information systems: a case study in Naqadeh, Iran," Environmental Monitoring and Assessment, vol. 191, no. 12, 12 pages, 2019.

[19] S. M. Monavari, P. Hoasami, S. Tajziehchi, N. Khorramichokami, and A. S. Area, "Study of solid waste landfill suitability using regional screening method and AHP in Rasht City," Int. J. Environ. Chem. Ecol. Geol. Geophys. Eng.vol. 6, no. 2, pp. 820-825, 2012.

[20] M. J. Buncag, L. M. Santos, and A. Magpantay, "Suitability analysis for sanitary landfill site in the province of ifugao, Philippines," International Journal of Science and Management Studies (IJSMS), vol. 2, no. 6, pp. 85-94, 2019.

[21] F. O. Ajibade, O. O. Olajire, T. F. Ajibade et al., "Combining multicriteria decision analysis with GIS for suitably siting landfills in a Nigerian state," Environmental and Sustainability Indicators, vol. 3-4, Article ID 100010, 2019.
[22] M. Mortazavi Chamchali and A. Ghazifard, "The use of fuzzy logic spatial modeling via GIS for landfill site selection (case study: rudbar-Iran)," Environmental Earth Sciences, vol. 78, no. 10, pp. 1-16, 2019.

[23] M. Saatsaz, I. Monsef, M. Rahmani, and A. Ghods, "Site suitability evaluation of an old operating landfill using AHP and GIS techniques and integrated hydrogeological and geophysical surveys," Environmental Monitoring and Assessment, vol. 190, no. 3, 2018.

[24] T. L. Saaty, "A scaling method for priorities in hierarchical structures," Journal of Mathematical Psychology, vol. 15, no. 3, pp. 234-281, 1977.

[25] M. K. Ayim, A. Fei-Baffoe, A. Sulemana, K. Miezah, and F. Adams, "Potential sites for landfill development in a developing country: a case study of Ga South Municipality, Ghana," Heliyon, vol. 5, no. 10, pp. e02537-54, 2019.

[26] O. Demesouka, A. Vavatsikos, and K. Anagnostopoulos, "GIS-based multicriteria municipal solid waste landfill suitability analysis: a review of the methodologies performed and criteria implemented," Waste Management \& Research: The Journal for a Sustainable Circular Economy, vol. 32, no. 4, pp. 270-296, 2014.

[27] J. Silveira dos Santos, A. Goncalves Girardi, and A. A. Brasil, "Utilização de geoprocessamento para localização de áreas para aterro sanitário no município de Alegrete-RS," in Proceedings of the Anais XIII Simpósio Brasileiro de Sensoriamento Remoto, Florianópolis, Brasil, April 2007.

[28] M. Chamchali, A. Mohebbi Tafreshi, and G. Mohebbi Tafreshi, "Utilizing GIS linked to AHP for landfill site selection in Rudbar County of Iran," Geojournal, vol. 86, no. 1, pp. 163-183, 2019.

[29] J. R. Adewumi, O. J. Ejeh, K. H. Lasisi, and F. O. Ajibade, “A GIS-AHP-based approach in siting MSW landfills in Lokoja, Nigeria," SN Applied Sciences, vol. 1, no. 12, 2019.

[30] A. Richter, K. T. W. Ng, and N. Karimi, "A data driven technique applying GIS, and remote sensing to rank locations for waste disposal site expansion," Resources, Conservation and Recycling, vol. 149, pp. 352-362, 2019.

[31] S. A. Ali and A. Ahmad, "Suitability analysis for municipal landfill site selection using fuzzy analytic hierarchy process and geospatial technique," Environmental Earth Sciences, vol. 79, no. 10, 2020.

[32] S. A. Ali, F. Parvin, N. Al-ansari, Q. B. Pham, A. Ahmad, and M. S. Raj, "Sanitary landfill site selection by integrating AHP and FTOPSIS with GIS: a case study of Memari Municipality, India," Environmental Science and Pollution Research, vol. 28, no. 6, pp. 7528-7550, 2020.

[33] H. Karimi, S. Amiri, J. Huang, and A. Karimi, "Integrating GIS and multi-criteria decision analysis for landfill site selection, case study: javanrood County in Iran," International journal of Environmental Science and Technology, vol. 16, no. 11, pp. 7305-7318, 2019.

[34] M. Çeliker, O. Yıldız, and N. N. Koçer, "Evaluating solid waste landfill site selection using multi-criteria decision analysis and geographic information systems in the city of Elazığ, Turkey," Pamukkale University Journal of Engineering Sciences, vol. 25, no. 6, pp. 683-691, 2019.

[35] Ș. Șener, E. Şener, B. Nas, and R. Karagüzel, “Combining AHP with GIS for landfill site selection: a case study in the Lake Beyşehir catchment area (Konya, Turkey)," Waste Management, vol. 30, no. 11, pp. 2037-2046, 2010.

[36] S. Cobos, J. Solano, A. Vera, and J. Monge, "Análisis multicriterio basado en GIS para identificar potenciales áreas de emplazamiento de un relleno sanitario mancomunado en la 
provincia del Azuay," p. 12, 2017, http://revistas.uazuay.edu. ec/index.php/memorias/article/view/48.

[37] F. Mohammadimanesh, B. Salehi, M. Mahdianpari, B. Brisco, and E. Gill, "Full and simulated compact polarimetry SAR responses to Canadian wetlands: separability analysis and classification," Remote Sensing, vol. 11, no. 5, pp. 516-525, 2019.

[38] H. Karimi, B. M. A. Herki, S. Q. Gardi et al., "Site selection and environmental risks assessment of medical solid waste landfill for the City of Kermanshah-Iran," International Journal of Environmental Health Research, vol. 00, no. 00, pp. 1-13, 2020.

[39] V. R. Sumathi, C. Sarkar, and U. Natesan, "GIS-based approach for optimized siting of municipal solid waste landfill," Waste Management, vol. 28, no. 11, pp. 2146-2160, 2008.

[40] R. Hazarika and A. Saikia, "Landfill site suitability analysis using AHP for solid waste management in the Guwahati Metropolitan Area, India," Arabian Journal of Geosciences, vol. 13, pp. 1-14, 2020.

[41] G. Sisay, S. L. Gebre, and K. Getahun, "GIS-based potential landfill site selection using MCDM-AHP modeling of Gondar Town, Ethiopia," African Geographical Review, vol. 40, no. 2, pp. 105-124, 2020.

[42] J. C. León Mendoza and L. Mendoza, "Capital humano y pobreza regional en Perú," Región Y Sociedad, vol. 31, pp. 1-23, 2019.

[43] INEI(Instituto Nacional de Estadística e Informática), "Características de la Población,” Perú Perf. Sociodemografico, vol. 2017, 2018.

[44] Defensoría del Pueblo, Dónde Va Nuestra Basura?, pp. 1-265, Defensoría del Pueblo, Lima, Perú, 2019, http://www. defensoria.gob.pe, Línea gratuita:0800-15170.

[45] MPCH (Municipalidad Provincial de Chachapoyas), "Estudio de Caracterización de residuos Sólidos Municipales," 2018, http://www.academia.edu/download/40955734/GERENCIA_ MUNICIPAL.pdf.

[46] OEFA (Organismo de Evaluación y Fiscalización Ambiental), Áreas Degradadas Por Residuos Sólidos Municipales, OEFA, Lima, Peru, 2019, https://sinia.minam.gob.pe/indicador/1627.

[47] J. Mego, J. Pilco, J. Chavez, D. Leiva, and M. Oliva, "Impacto en la calidad del agua de la quebrada 'El Atajo' ocasionado por el botadero de rondón de la ciudad de Chachapoyas, Amazonas, Perú," Rev. Indes, vol. 2, no. 1, pp. 80-87, 2016.

[48] J. F. Silva, R. K. A. d. Silva, Y. M. Paz, J. V. d. Reis, H. D. S. Ferreira, and A. L. B. Candeias, "Avaliação do sensoriamento remoto termal para monitoramento de aterros sanitários," Journal of Environmental Analysis and Progress, vol. 3, no. 1, pp. 037-048, 2018.

[49] E. Tercan, M. A. Dereli, and S. Tapkın, "A GIS-based multicriteria evaluation for MSW landfill site selection in Antalya, Burdur, Isparta planning zone in Turkey," Environmental Earth Sciences, vol. 79, no. 10, pp. 1-17, 2020.

[50] S. Djokanović, B. Abolmasov, and D. Jevremović, "GIS application for landfill site selection: a case study in Pančevo, Serbia," Bulletin of Engineering Geology and the Environment, vol. 75, no. 3, pp. 1273-1299, 2016.

[51] MINAM (Ministerio del Ambiente), Guía de: Diseño, construcción, operación, mantenimiento y cierre de relleno sanitario mecanizado, pp. 29-35, MINAM, Lima, Perú, 2008, https://www.minam.gob.pe/calidadambiental/residuos.

[52] T. Hengl, J. Mendes de Jesus, G. B. M. Heuvelink et al., "SoilGrids250m: global gridded soil information based on machine learning," PLoS One, vol. 12, no. 2, pp. e0169748-40, 2017.
[53] INGEMMET (Instituto Geológico, Minero y Metalúrgico), "IMGEMMET BOLETIN No. A 55: Geología del Perú," Ingemmet, vol. A, no. 55, p. 177, 1995, https://hdl.handle.net/ 20.500.12544/176.

[54] S. E. Fick and R. J. Hijmans, "WorldClim 2: new 1-km spatial resolution climate surfaces for global land areas," International Journal of Climatology, vol. 37, no. 12, pp. 4302-4315, 2017.

[55] MINEDU, "Descarga de información espacial del Ministerio de Educación," p. 2020, 2020, http://sigmed.minedu.gob.pe/ descargas/ [Online]. Available:.

[56] N. Puletti, F. Chianucci, and C. Castaldi, "Use of Sentinel-2 for forest classification in Mediterranean environments," Ann. Silvic. Res.vol. 42, no. 1, pp. 32-38, 2018.

[57] SERNANP (Servicio Nacional de Áreas Naturales Protegidas por el Estado), GEO ANP-Visor de las Áreas Naturales Protegidas, https://geo.sernanp.gob.pe/visorsernanp/, p. 2020, SERNANP, Lima, Peru, 2020, .

[58] MTC (Ministerio de Transportes y Comunicaciones), Descarga de datos espaciales, MTC, Cercado de Lima, Peru, p. 1, 2017, https://portal.mtc.gob.pe/estadisticas/descarga.html.

[59] J. Biluca, C. R. de Aguiar, F. Trojan, and F. Trojan, "Sorting of suitable areas for disposal of construction and demolition waste using GIS and ELECTRE TRI," Waste Management, vol. 114, pp. 307-320, 2020.

[60] Z. K. Motlagh and M. H. Sayadi, "Siting MSW landfills using MCE methodology in GIS environment (Case study: b," , 2015.

[61] O. E. Demesouka, A. P. Vavatsikos, and K. P. Anagnostopoulos, "Using MACBETH multicriteria technique for GIS-based landfill suitability analysis," Journal of Environmental Engineering, vol. 142, no. 10, pp. 1-11, 2016.

[62] F. Sar1, D. A. Ceylan, M. M. Özcan, and M. M. Özcan, "A comparison of multicriteria decision analysis techniques for determining beekeeping suitability," Apidologie, vol. 51, no. 4, pp. 481-498, 2020.

[63] R. W. Saaty, "The analytic hierarchy process-what it is and how it is used," Mathematical Modelling, vol. 9, no. 3-5, pp. 161-176, 1987.

[64] T. L. Saaty, "The implementation of management science in higher education administration," International Journal of Services Sciences, vol. 15, no. 4, pp. 283-290, 1987.

[65] S. Bozóki and T. Rapcsák, "s inconsistencies of pairwise comparison matrices," Journal of Global Optimization, vol. 42, no. 2, pp. 157-175, 2008.

[66] C. R. C. Yunis, R. Salas López, S. M. O. Cruz et al., "Land suitability for sustainable aquaculture of rainbow trout (Oncorhynchus mykiss) in molinopampa (Peru) based on RS, GIS, and AHP," ISPRS International Journal of Geo-Information, vol. 9, no. 1, p. 28, 2020.

[67] Z. Ding, M. Zhu, Z. Wu, Y. Fu, and X. Liu, "Combining AHPentropy approach with GIS for construction waste landfill selection-a case study of Shenzhen," International Journal of Environmental Research and Public Health, vol. 15, no. 10, 2018.

[68] A. Najjari and K. Shayesteh, "Site selection for hazardous waste using FuzzyLogic combined with analytic hierarchy process: ACase study in nahavand, Iran," Avicenna Journal of Environmental Health Engineering, vol. 6, no. 1, pp. 8-15, 2019.

[69] L. L. Moreira, D. Schwamback, N. R. Corrêa, and A. L. N. Coelho, "Sig aplicado à seleção de áreas potenciais para instalação de aterro sanitário no município de serra - es," Geociencias, vol. 35, no. 4, pp. 531-541, 2016. 
[70] I. Palacios, "Relleno sanitario en La ciudad de macas, a través de La ponderación de Sus variables con el proceso," Rev. Ciencias Segur. y Def.vol. III, no. 3, pp. 83-94, 2018.

[71] M. Aduriz, A. Gargano, P. Chimeno, M. Saldungaray, and V. Conti, "Caracterización de los agrosistemas predominantes de la Cuenca Alta del río Sauce Grande," Rev. Investig. Agropecu.vol. 32, no. 3, pp. 3-26, 2003.

[72] H. Y. Lin and J. J. Kao, "A vector-based spatial model for landfill siting," Journal of Hazardous Materials, vol. 58, no. $1-3$, pp. 3-14, 1998.

[73] H. Karimi, A. Soffianian, S. Seifi, S. Pourmanafi, and H. Ramin, "Evaluating optimal sites for combined-cycle power plants using GIS: comparison of two aggregation methods in Iran," International Journal of Sustainable Energy, vol. 39, no. 2, pp. 101-112, 2020.

[74] P. de Medeiros Engelmann, V. H. J. M. dos Santos, L. I. Moser et al., "Environmental monitoring of water resources around a municipal landfill of the Rio Grande do Sul state, Brazil," Environmental Science and Pollution Research, vol. 24, no. 26, pp. 21398-21411, 2017.

[75] M. Eghtesadifard, P. Afkhami, and A. Bazyar, "An integrated approach to the selection of municipal solid waste landfills through GIS, K-Means and multi-criteria decision analysis," Environmental Research, vol. 185, 2020.

[76] M. Barzehkar, N. M. Dinan, S. Mazaheri, R. M. Tayebi, and G. I. Brodie, "Landfill site selection using GIS-based multicriteria evaluation (case study: SaharKhiz Region located in Gilan Province in Iran)," SN Applied Sciences, vol. 1, no. 9, pp. 1-11, 2019.

[77] E. H. W. F. K. Kirimi, "Determination of suitable landfill site using geospatial techniques and multi-criteria decision analysis: a case study of nakuru town, Kenya," International Journal of Scientific Research, vol. 3, no. 11, pp. 500-505, 2014, [Online]. Available:

[78] B. Şener, M. L. Süzen, and V. Doyuran, "Landfill site selection by using geographic information systems," Environmental Geology, vol. 49, no. 3, pp. 376-388, 2006.

[79] F.-B. Mustafa and B. E. Bwadi, "Determination of optimal freshwater prawn farming site locations using GIS and multicriteria evaluation," Journal of Coastal Research, vol. 82, pp. 41-54, 2018.

[80] MINAM (Ministerio del Ambiente), Guía metodológica para la elaboración de los instrumentos técnicos sustentatorios para el Ordenamiento Territorial, MINAM, Lima, Perú, 2015.

[81] MINAM (Minsterio del Ambiente), Programa de Recuperación de Áreas Degradadas por Residuos Solidos, MINAM, Lima, Perú, 2015.

[82] D. el Peruano, "Resolución Ministerial N ${ }^{\circ}$ 099-2019MINAM," Lima, 2019, https://busquedas.elperuano.pe/ normaslegales/declaran-en-emergencia-la-gestion-y-manejode-los-residuos-s-resolucion-ministerial-n-099-2019-minam1758096-1/. 